\title{
PENAMBAHAN TEPUNG TULANG IKAN LELE TERHADAP KADAR KALSIUM DAN ORGANOLEPTIK COOKIES UBI JALAR KUNING
}

\author{
Titik Dwi Sulistiyatia, dan Olvin Mawaddah ${ }^{\mathrm{a}}$ \\ ${ }^{\text {a}}$ Fakultas Perikanan dan Ilmu Kelautan Universitas Brawijaya \\ Jl. Veteran, Malang - Indonesia \\ *Koresponden penulis : olvinmwdh@gmail.com
}

\begin{abstract}
Abstrak
Penambahan tepung tulang ikan pada pembuatan cookies ubi jalar kuning dapat dilakukan guna menjadi sumber kalsium pada cookies ubi jalar kuning. Tujuan dari penelitian ini adalah untuk mengetahui konsentrasi penambahan tepung tulang ikan lele yang terbaik terhadap kadar kalsium dan organoleptik cookies ubi jalar kuning. Percobaan dirancang menggunakan Rancangan Acak Lengkap (RAL) sederhana. Hasil terbaik terdapat pada perlakuan E (penambahan $10 \%$ tepung tulang ikan lele) yang menghasilkan kadar kalsium $0,23 \%$, hedonik warna 3,19 , hedonik aroma 3,33 , hedonik rasa 3,41 dan hedonik tekstur 3,25.
\end{abstract}

Kata kunci: cookies ubi jalar kuning, kalsium, tepung tulang ikan lele

\begin{abstract}
Addition of fish bone meal of production yellow sweet potato cookies can be do to be assource of calsium. The purpose of this research was to know the concentration of the addition of the best catfish bone meal to calcium content and organoleptic of yellow sweet potato cookies. The experiment was designed using simple completely randomized design (RAL). The best results based on yellow sweet potato cookies with the addition of fish bone meal were found in treatment E (adding 10\% of catfish bone meal) with the following values, calcium content of $0,23 \%$, hedonic colour of 3,19 , hedonic flavor of 3,33 , hedonic taste of 3,41 , and hedonic texture of 3,25 .
\end{abstract}

Keywords: yellow sweet potato cookies, calcium, catfish bone meal

\section{PENDAHULUAN}

Cookies merupakan salah satu jenis biskuit yang terbuat dari adonan lunak, memiliki tekstur yang renyah, tipis, datar dan biasanya berbentuk gepeng. Bahan dasar pembuatan cookies adalah tepung terigu [1]. Tepung terigu merupakan kerangka adonan dalam pembuatan cookies, disebut dalam kerangka adonan karena kandungan pati dan protein pada tepung terigu akan menyerap cairan pada adonan. Peran tepung terigu dalam pembuatan cookies dapat digantikan dengan tepung jenis lain seperti tepung tapioka, tepung mocaf, dan tepung jagung [2].

Cookies ubi jalar kuning merupakan produk diversifikasi dengan penambahan tepung ubi jalar kuning pada proses pembuatan cookies. Tepung ubi jalar dapat dimanfaatkan untuk substitusi tepung terigu sampai dengan 50\% dalam pembuatan aneka kue kering dan cake [3]. Penggunaan ubi jalar dalam bentuk tepung ubi jalar secara fleksibel mudah untuk digunakan pada produk pangan.

Ikan lele merupakan jenis ikan air tawar yang banyak dikonsumsi oleh masyarakat Indonesia. Tingginya tingkat konsumsi menyebabkan ketersediaan ikan lele juga melimpah. Sejauh ini pada home industry ikan lele diolah menjadi abon, fillet, nugget, otakotak dll. Banyaknya produksi ikan lele pada home industry menyebabkan meningkatnya jumlah limbah yang dihasilkan, salah satunya adalah bagian tulang ikan [4].

Kandungan mineral kalsium pada tulang ikan dapat dimanfaatkan dalam bidang pangan, akan tetapi sebelum diaplikasikan tulang ikan perlu diolah menjadi tepung agar mudah dalam pengaplikasiannya. Kandungan gizi kalsium pada tepung tulang ikan lele 
mencapai $13,48 \%$ [5]. Kandungan kalsium pada tulang ikan dapat menjadi sumber alternatif untuk pemenuhan kebutuhan kalsium dalam tubuh [6]. Kalsium pada tubuh dapat bermanfaat untuk pembentukan dan pemeliharaan tulang dan gigi. Kalsium juga dibutuhkan untuk proses pembentukan dan perawatan jaringan rangka tubuh serta beberapa kegiatan penting dalam tubuh seperti pembekuan darah, kontraksi otot, menjaga keseimbangan hormon dan katalisator pada reaksi biologis[7].

Angka Kecukupan Gizi (AKG) menyebutkan bahwa konsumsi kalsium per hari untuk remaja yaitu $1000 \mathrm{mg}$ dan dewasa $800 \mathrm{mg}$. Salah satu dampak dari defisiensi kalsium yang banyak terjadi adalah osteoporosis yang ditandai dengan hilangnya kepadatan tulang setelah mencapai usia tua. Pada anak-anak defisiensi kalsium dapat menyebabkan terhambatnya pertumbuhan tulang. Melihat tingginya kebutuhan kalsium dan beratnya dampak yang ditimbulkan apabila kekurangan, maka perlu dikembangkan suatu produk untuk meningkatkan keragaman produk makanan sumber kalsium yang dapat dikonsumsi masyarakat untuk memenuhi kebutuhan kalsium tubuh [8].

\section{MATERI DAN METODE}

\section{Bahan dan Peralatan Penelitian}

Bahan yang digunakan dalam pembuatan tepung tulang ikan lele (Clarias sp.) adalah tulang ikan lele (Clarias sp.) yang diperoleh dari UKM Farm Fish Boster Centre, akuades dan $\mathrm{NaOH}$. Bahan yang digunakan dalam pembuatan cookies adalah tepung terigu, tepung ubi jalar kuning, margarin, gula halus, susu bubuk, baking powder, telur, garam, chocochip dan kertas roti. Sedangkan bahan yang digunakan dalam analisis laboratoris adalah asam nitrat $\left(\mathrm{HNO}_{3}\right)$, air $\left(\mathrm{H}_{2} \mathrm{O}\right)$, lantanum dan aquadenim.

Alat yang digunakan untuk proses pembuatan tepung tulang ikan lele adalah baskom, panci, kompor, loyang, oven listrik, blender dan ayakan 100 mesh. Alat yang digunakan untuk pembuatan cookies menggunakan baskom, mixer, timbangan digital, timbangan analitik, loyang dan oven listrik. Alat yang digunakan dalam analisis laboratoris adalah timbangan analitik, Atomic Absorbtion Spectrophotometer (AAS) dengan panjang gelombang 422,7 $\mathrm{nm}$ dan labu takar.

\section{Prosedur Penelitian}

Rancangan penelitian menggunakan Rancangan Acak Lengkap (RAL) dengan 4 kali ulangan. Faktor utama yaitu penambahan tepung tulang ikan lele dengan persentase $\mathrm{A}$ $(0 \%), \mathrm{B}(2,5 \%), \mathrm{C}(5 \%), \mathrm{D}(7,5 \%)$, dan E (10\%) dari total tepung yang digunakan. Analisis data menggunakan ANOVA dan dilanjutkan uji Duncan dengan taraf $5 \%$. Parameter organoleptik dianalisis dengan uji non parametrik Kruskal Wallis.

\section{Proses Pembuatan Tepung Tulang Ikan Lele}

Prosedur yang digunakan dalam pembuatan tepung tulang ikan lele mengacu pada penelitian yang dilakukan oleh Syah et al. (2018) yang telah dimodifikasi. Tahap pertama yang dilakukan adalah tulang ikan lele direbus selama 30 menit pada suhu $90^{\circ} \mathrm{C}$. Selanjutnya dilakukan perebusan menggunakan $\mathrm{NaOH} 0,1 \mathrm{~N}$ dengan suhu $90^{\circ} \mathrm{C}$ selama 10 menit. Kemudian tulang ikan dicuci menggunakan air hingga mencapai $\mathrm{pH}$ netral (7), lalu dikeringkan menggunakan oven dengan suhu $50^{\circ} \mathrm{C}$ selama 12 jam. Tahap selanjutnya adalah penggilingan tulang ikan menggunakan blender. Setelah itu tepung tulang diayak menggunakan ayakan berukuran 100 mesh.

\section{Proses Pembuatan Cookies Ubi Jalar Kuning}

Prosedur yang digunakan dalam pembuatan cookies ubi jalar kuning mengacu pada penelitian yang dilakukan oleh Taufik et al. (2019) yang telah dimodifikasi. Proses pembuatan cookies diawali dengan persiapan bahan-bahan untuk 1 formulasi yaitu margarin sebanyak $75 \mathrm{~g}$, gula halus $50 \mathrm{~g}$, kuning telur $25 \mathrm{~g}$, tepung terigu $50 \mathrm{~g}$, tepung ubi jalar kuning $50 \mathrm{~g}$, susu bubuk $10 \mathrm{~g}$, garam $0,5 \mathrm{~g}$, baking powder 1,5 g dan chocochip $2 \mathrm{~g}$. Selanjutnya dibuat cookies ubi jalar kuning yang terdiri dari tiga tahap, yaitu pengadonan, pencetakan dan pemanggangan. Pertama 
dilakukan pengocokan margarin, kuning telur dan gula halus selama \pm 5 menit. Kemudian ditambahkan tepung terigu, tepung ubi jalar kuning, tepung tulang ikan lele, susu bubuk, garam dan baking powder lalu diaduk sampai kalis. Selanjutnya dilakukan pencetakan dan ditata diatas loyang lalu dilakukan pemberian chocochip di atas cookies yang sudah dicetak. Kemudian dipanggang menggunakan oven pada suhu $170^{\circ} \mathrm{C}$ selama 15 menit. Setelah matang diangkat dan didinginkan. Selanjutnya dilakukan pengujian kadar kalsium dan organoleptik (warna, aroma, rasa dan tekstur).

\section{Uji Kadar Kalsium}

Prosedur yang digunakan dalam pengujian kadar kalsium mengacu pada penelitian yang dilakukan oleh Syah et al. (2018). Penentuan kadar kalsium dilakukan dengan menimbang sampel \pm 5 g kemudian mengabukan. Sampel abu tersebut didestruksi dengan menambahkan $\mathrm{HNO}_{3}: \mathrm{H}_{2} \mathrm{O}$ (10:30) selama \pm 10 menit. Larutan hasil destruksi didinginkan kemudian disaring dan ditempatkan pada labu takar $50 \mathrm{ml}$. Aquademin ditambahkan hingga tanda tera pada labu takar $50 \mathrm{ml}$. Larutan ini dinamakan larutan indukan. Kemudian dilakukan pengenceran dengan cara mengambil $0,5 \mathrm{ml}$ larutan indukan dan dimasukkan ke dalam labu takar $10 \mathrm{ml}$ serta menambahkan aquademin hingga tanda tera. Tahap pembacaan dengan mengambil $0,5 \mathrm{ml}$ larutan yang telah diencerkan kemudian dimasukkan dalam labu takar $10 \mathrm{ml}$ dan ditambahkan $2 \mathrm{ml}$ lantanum dan aquademin hingga tanda tera. Pembacaan sampel dilakukan pada Atomic Absorbtion Spectrophotometer (AAS) dengan panjang gelombang 422,7 nm. Kadar kalsium dapat dihitung menggunakan rumus sebagai berikut:

$\% \mathrm{Ca}=\frac{\text { Konsentasi } \mathrm{x} \text { volume indukan } \mathrm{x} \text { pengenceran }}{\text { Berat sampel } \mathrm{x} 10000}$

\section{Uji Organoleptik}

Uji organoleptik meliputi warna, aroma, rasa, dan tekstur pada cookies ubi jalar kuning dengan skala pembobotan kesukaan 1-4, dimana skala: $1=$ sangat tidak suka, $2=$ tidak suka, 3 = suka, 4 = sangat yang menggunakan 100 panelis tidak terlatih yaitu mahasiswa
Universitas Brawijaya. Penilaian dilakukan pada cookies ubi jalar kuning untuk warna, aroma, rasa, tekstur sebagai indikator penilaian dengan memberikan kuesioner hedonik.

\section{HASIL DAN PEMBAHASAN}

\section{Kadar Kalsium}

Kadar kalsium cookies ubi jalar kuning berkisar antara $0,10 \pm 0,02 \%$ hingga $0,23 \% \pm 0,06 \%$. Hasil analisis statistika menunjukkan bahwa penambahan tepung tulang ikan lele berpengaruh nyata $(\mathrm{P}<0,05)$ terhadap kadar kalsium cookies ubi jalar kuning. Kadar kalsium cookies ubi jalar kuning dapat dilihat pada Tabel 1.

Tabel 1. Kadar kalsium cookies ubi jalar kuning dengan penambahan tepung tulang ikan lele

\begin{tabular}{cc}
\hline Perlakuan & Kadar Kalsium $(\%)$ \\
\hline A & $0,10 \pm 0,02^{\mathrm{a}}$ \\
B & $0,11 \pm 0,03^{\mathrm{a}}$ \\
C & $0,12 \pm 0,04^{\mathrm{ab}}$ \\
D & $0,18 \pm 0,06^{\mathrm{bc}}$ \\
E & $0,23 \pm 0,06^{\mathrm{c}}$ \\
\hline
\end{tabular}

Keterangan: Notasi huruf yang sama menunjukkan tidak berbeda nyata

Penambahan tepung tulang ikan lele dapat meningkatkan kadar kalsium pada cookies ubi jalar kuning. Hal tersebut disebabkan karena tepung tulang ikan lele mengandung kalsium sebesar $1,77 \%$ yang tercampur pada adonan saat proses pembuatan cookies ubi jalar kuning. Dimana tepung tulang akan dilarutkan oleh bahan-bahan lainnya sehingga bahan tersebut terdispersi secara merata di dalam adonan yang menyebabkan kadar kalsium pada cookies ubi jalar kuning meningkat. Tulang ikan mengandung mineral dan kalsium sehingga akan mempengaruhi nilai kalsium suatu produk yang dibuat dengan penambahan tepung tulang ikan. Semakin tinggi konsentrasi tepung tulang ikan yang ditambahkan pada produk maka akan semakin tinggi pula kadar kalsium yang akan dihasilkan [9]. 


\section{Karakteristik Organoleptik}

Pengujian organoleptik bertujuan untuk mengetahui tingkat penerimaan panelis terhadap cookies ubi jalar kuning dengan penambahan tepung tulang ikan lele. Pengujian organoleptik pada cookies ubi jalar kuning ini dilakukan secara hedonik (kesukaan). Uji hedonik bertujuan untuk mengetahui respons panelis terhadap sifat mutu yang umum yaitu warna, aroma, tekstur dan rasa. Dalam uji ini panelis diminta mengungkapkan tanggapan pribadinya tentang kesukaan atau ketidaksukaan [10]. Karakteristik organoleptik cookies ubi jalar kuning dengan penambahan tepung tulang ikan lele dapat dilihat pada Tabel 2.

Tabel 2. Karakteristik organoleptik cookies ubi jalar kuning dengan penambahan tepung tulang ikan lele

\begin{tabular}{ccccc} 
& Warna & Aroma & Rasa & Tekstur \\
\hline \multirow{2}{*}{ A } & $3,33 \pm$ & $3,21 \pm$ & $3,37 \pm$ & $3,27 \pm$ \\
& 0,62 & 0,60 & 0,61 & 0,63 \\
B & $3,31 \pm$ & $3,16 \pm$ & $3,22 \pm$ & $3,16 \pm$ \\
& 0,56 & 0,63 & 0,64 & 0,66 \\
& $3,13 \pm$ & $3,11 \pm$ & $3,17 \pm$ & $3,24 \pm$ \\
C & 0,67 & 0,64 & 0,69 & 0,57 \\
& $3,24 \pm$ & $3,20 \pm$ & $3,40 \pm$ & $3,37 \pm$ \\
D & 0,57 & 0,61 & 0,65 & 0,56 \\
& $3,19 \pm$ & $3,33 \pm$ & $3,41 \pm$ & $3,25 \pm$ \\
E & 0,64 & 0,55 & 0,62 & 0,59 \\
\hline
\end{tabular}

Skala: 1 = sangat tidak suka, 2 = tidak suka, 3 = suka, $4=$ sangat suka

\section{Warna}

Warna cookies ubi jalar kuning memiliki nilai hedonik antara $3,13 \pm 0,67$ hingga 3,33 $\pm 0,62$. Hasil analisis statistik Kruskal Wallis menunjukkan bahwa penambahan tepung tulang ikan lele tidak berpengaruh nyata $(\mathrm{P}>0,05)$ terhadap warna cookies ubi jalar kuning. Hasil organoleptik dapat dilihat pada Tabel 2.

Nilai rata-rata hedonik warna tertinggi terdapat pada perlakuan A $(0 \%$ penambahan tepung tulang ikan lele) yaitu sebesar $(3,33 \pm 0,62)$ sedangkan rata-rata terendah terdapat pada perlakuan $\mathrm{C}$ (5\% penambahan tepung tulang ikan lele) yaitu sebesar
$(3,13 \pm 0,67)$. Dapat disimpulkan bahwa warna cookies yang paling disukai panelis yaitu perlakuan A $(0 \%)$ yang memiliki warna coklat keemasan.

Warna pada cookies dipengaruhi oleh bahan-bahan yang digunakan dalam proses pembuatannya yaitu lemak, gula dan telur. Warna pada cookies juga dipengaruhi pada saat proses pemanggangan [11]. Pada saat proses pemanggangan cookies terjadi pencokelatan (browning reaction) yaitu reaksi maillard. Reaksi maillard merupakan reaksi antara karbohidrat, khususnya gula pereduksi dengan gugus amino primer dari protein yang menghasilkan senyawa hidroksimetrifurfural yang kemudian berlanjut menjadi furfural. Furfural yang terbentuk berpolimer membentuk senyawa melanoidin yang berwarna kecokelatan. Melanoidin inilah yang memberikan warna coklat keemasan pada cookies yang dihasilkan [12].

\section{Aroma}

Aroma cookies ubi jalar kuning memiliki nilai hedonik antara $3,11 \pm 0,64$ hingga 3,33+0,55. Hasil analisis statistik Kruskal Wallis menunjukkan bahwa penambahan tepung tulang ikan lele tidak berpengaruh nyata $(\mathrm{P}>0,05)$ terhadap aroma cookies ubi jalar kuning. Hasil organoleptik dapat dilihat pada Tabel 2.

Nilai rata-rata hedonik aroma tertinggi terdapat pada perlakuan E (10\% penambahan tepung tulang ikan lele) yaitu sebesar $(3,33 \pm 0,55)$ sedangkan rata-rata terendah terdapat pada perlakuan C $(5 \%$ penambahan tepung tulang ikan lele) yaitu sebesar $(3,11 \pm 0,64)$. Dapat disimpulkan bahwa aroma cookies yang paling disukai panelis yaitu perlakuan E (10\%) yang memiliki aroma cookies yang sangat kuat.

Komponen yang memberikan aroma adalah asam-asam organik berupa ester dan volatil. Adanya kandungan pati yang tergradasi saat pemanggangan adonan cookies. Kandungan pati terjadi perubahan yang ekstensif dengan eliminasi molekul air dan fragmentasi molekul gula dimana terjadi pemutusan ikatan karbon yang menghasilkan senyawa karbonil dan volatil sehingga menghasilkan aroma yang khas pada cookies. 
Penggunaan margarin pada pembuatan cookies dapat memperkuat aroma yang cookies dihasilkan. Lemak merupakan salah satu komponen penting dalam pembuatan cookies karena berfungsi sebagai penambah aroma [13].

\section{Rasa}

Rasa cookies ubi jalar kuning memiliki nilai hedonik antara 3,17 $\pm 0,69$ hingga $3,41 \pm 0,62$. Hasil analisis statistik Kruskal Wallis menunjukkan bahwa penambahan tepung tulang ikan lele memberikan berpengaruh nyata $(\mathrm{P}<0,05)$ terhadap rasa cookies ubi jalar kuning. Hasil organoleptik dapat dilihat pada Tabel 2.

Nilai rata-rata tertinggi terdapat pada perlakuan E (10\% penambahan tepung tulang ikan lele) yaitu sebesar $(3,41 \pm 0,62)$, sedangkan rata-rata terendah terdapat pada perlakuan $\mathrm{C}(5 \%$ penambahan tepung tulang ikan lele) yaitu sebesar $(3,17 \pm 0,69)$. Dapat disimpulkan bahwa rasa cookies yang paling disukai panelis yaitu perlakuan E (10\%) yang memiliki rasa cookies yang sangat kuat. Secara keseluruhan panelis menyukai semua perlakuan penambahan tepung tulang ikan lele. Timbulnya rasa pada cookies dapat disebabkan oleh bahan-bahan dalam formulasi cookies terutama gula dan lemak [14].

\section{Tekstur}

Tekstur cookies ubi jalar kuning memiliki nilai hedonik antara $3,11 \pm 0,64$ hingga 3,33 $\pm 0,55$. Hasil analisis statistik Kruskal Wallis menunjukkan bahwa penambahan tepung tulang ikan lele tidak berpengaruh nyata $(\mathrm{P}>0,05)$ terhadap tekstur cookies ubi jalar kuning. Hasil organoleptik dapat dilihat pada Tabel 2 .

Nilai rata-rata tertinggi terdapat pada perlakuan $\mathrm{D}(7,5 \%$ penambahan tepung tulang ikan lele) yaitu sebesar $(3,37 \pm 0,56)$, sedangkan rata-rata terendah terdapat pada perlakuan B (2,5\% penambahan tepung tulang ikan lele) yaitu sebesar $(3,16 \pm 0,66)$. Dapat disimpulkan bahwa tekstur cookies yang paling disukai panelis yaitu perlakuan D (7,5\%) yang memiliki tekstur cookies yang sangat renyah.
Tekstur cookies pada umumnya adalah renyah dan tidak keras. Baik buruknya tekstur suatu makanan dipengaruhi oleh kadar air, kandungan lemak, protein dan jumlah serta jenis karbohidratnya[15]. Faktor lain yang mempengaruhi tekstur cookies adalah lemak. Bahan tambahan pangan yang mengandung lemak digunakan pada pembuatan cookies adalah margarin, kuning telur. Margarin dan kuning telur memiliki kandungan lemak yang tinggi, hal ini dapat menghasilkan tekstur cookies yang mudah rapuh/renyah [16].

\section{KESIMPULAN}

Hasil penelitian menunjukkan bahwa perlakuan terbaik terdapat pada perlakuan $\mathrm{E}$ yaitu dengan penambahan tepung tulang ikan lele sebanyak $10 \%$ dengan kadar kalsium $0,23 \%$, hedonik warna 3,19 (suka-sangat suka), hedonik aroma 3,33 (suka-sangat suka), hedonik rasa 3,41 (suka-sangat suka) dan hedonik tekstur 3,25 (suka-sangat suka).

\section{DAFTAR PUSTAKA}

[1] R. H. Subandoro, Basito dan W. Atmaka. Pemanfaatan tepung millet kuning dan tepung ubi jalar kuning sebagai substitusi tepung terigu dalam pembuatan cookies terhadap karakteristik organoleptik dan fisikokimia. Jurnal Tenosains Pangan. 2 (4): 68-74. 2013.

[2] T. W. Agustini, A. S. Fahmi, I. Widowati dan A. Sarwono. Pemanfaatan limbah cangkang kerang simping (Amusium pleuronectes) dalam pembuatan cookies kaya kalsium. Jurnal Pengolahan Hasil Perikanan. 14 (1): 8-13. 2016.

[3] S. Widowati. Diversifikasi konsumsi pangan berbasis ubi jalar. Pangan. 20 (1): 49-61. 2011.

[4] Y. Permata, F. Widiatri, Y. Sudaryanto dan A. Anteng. Gelatin dari tulang ikan lele (Clarias batrachus) pembuatan dengan metode asam, karakterisasi dan 
aplikasinya sebagai thickener pada industri sirup. Jurnal Ilmiah Widya Teknik. 15 (2): 146-152. 2016.

[5] F. K. Sari, D. Ishartani, N. H. Parnanto dan C. Anam. Pengaruh penambahan tulang ikan lele (clarias sp) dan kacang tunggak (Vigna unguiculata) terhadap kandungan kalsium dan protein pada susu jagung manis (Zea mays saccharata). Jurnal Teknosains Pangan. 2 (1): 66-72. 2013.

[6] S. Bakhtiar, Rohaya dan M. Ayunda. Penambahan tepung tulang ikan bandeng (chanos chanos) sebagai sumber kalsium dan fosfor pada pembuatan donat panggang. Jurnal Teknologi dan Industri Pertanian Indonesia. 11 (1): 38-35. 2019

[7] M. Edam. Fortifikasi tepung tulang ikan terhadap karakteristik fisiko-kimia bakso ikan. Jurnal Penelitian Teknologi Industri. 8 (2): 83-90. 2016.

[8] H. Ferazuma, S. A. Marliyati dan L. Amalia. Substitusi tepung kepala ikan lele dumbo (Clarias Gariepinus sp) untuk meningkatkan kandungan kalsium crackers. Journal of Nutrition and Food. 6 (1): 18-27. 2011.

[9] Salitus, D. Iminingtyas dan E. Fatarina. Penambahan tepung tulang bandeng (Chanos chanos) dalam pembuatan kerupuk sebagai hasil samping industri bandeng cabut duri. Jurnal Ilmiah UNTAG Semarang. 6 (2): 81-92. 2017.

[10] D.I. Bunta, A. S. Naiu dan N. S. Yusuf. Pengaruh penambahan tepung tulang ikan tuna terhadap karakteristik kue bagea khas Gorontalo. Jurnal Ilmiah
Perikanan dan Kelautan. 1 (2): 81-88. 2013.

[11] Darmawangsyah. Jamaluddin dan Kadirman. Fortifikasi tepung tulang ikan bandeng (Chanos chanos) dalam pembuatan kue kering. Jurnal Pendidikan Teknologi Pertanian. 2: 149-156.2016.

[12] H. Fajiarningsih. Pengaruh penggunaan komposit tepung kentang (Solanum tuberosum L) terhadap kualitas cookies. Food Science and Culinary Education Journal . 2 (1): 36-44. 2013.

[13] A. S. Oktaviani, W. Hesoelistyorini dan Nurhidajah. Kadar protein, daya kembang dan organoleptik cookies dengan substitusi tepung mocaf dan tepung pisang kepok. Jurnal pangan dan gizi. 7 (2): 72-81. 2017.

[14] T. W. Agustini, A. S. Fahmi, I. Widowati dan A. Sarwono. Pemanfaatan limbah cangkang kerang simping (Amusium pleuronectes) dalam pembuatan cookies kaya kalsium. Jurnal Pengolahan Hasil Perikanan. 14 (1): 8-13. 2016.

[15] Y. K. Sari dan A. C. Adi. Daya terima, kadar protein dan zat besi cookies subtitusi tepung daun kelor dan tepung kecambah kedelai. Media Gizi Indonesia. 12 (1): 27-33. 2017.

[16] W. Marsigit, Bonodikun dan L. Sitanggang. Pengaruh penambahan baking powder dan air terhadap karakteristik sensoris dan sifat fisik biskuit mocaf (modified cassava flour). Jurnal Agroindustri. 7 (1): 1-10. 2017. 